\title{
Ectomycorrhizal communities of Quercus garryana are similar on serpentine and nonserpentine soils
}

\author{
A. Mariah Moser • Jonathan L. Frank • \\ Jad A. D'Allura • Darlene Southworth
}

Received: 17 March 2008 / Accepted: 1 August 2008 / Published online: 16 August 2008

(C) The Author(s) 2008. This article is published with open access at Springerlink.com

\begin{abstract}
Serpentine soils, rich in iron, magnesium, and heavy metals, select for unique plant communities and for endemic species. Because mycorrhizal fungi mediate the interaction between plants and soil, we hypothesized that distinct ectomycorrhizal fungi would colonize Quercus garryana roots on serpentine and nonserpentine soils. We sampled roots of $Q$. garryana on serpentine soils at two locations in the Klamath-Siskiyou Mountains of southwestern Oregon and identified ectomycorrhizas by morphological and molecular methods. The same six most abundant and most frequent mycorrhizal species, Cenococcum geophilum, Tuber candidum, Genea harknessii, Tomentella sp., Sebacina sp., and Inocybe sp., were found on serpentine and nonserpentine soils. Based on similarities calculated using the Sørensen index in Non-metric Multidimensional Scaling, mycorrhizal communities on serpentine and nonserpentine soils were not significantly different. This study showed
\end{abstract}

Electronic supplementary material The online version of this article (doi:10.1007/s11104-008-9743-9) contains supplementary material, which is available to authorized users.

Responsible Editor: Erik A. Hobbie.

A. M. Moser · J. L. Frank • D. Southworth $(\bowtie)$

Department of Biology, Southern Oregon University, Ashland, OR 97520, USA

e-mail: southworth@sou.edu

J. A. D'Allura

Department of Geology, Southern Oregon University,

Ashland, OR 97520, USA that ectomycorrhizal species associated with $Q$. garryana exhibit edaphic tolerance and were neither reduced nor excluded by serpentinite or peridotite parent materials.

Keywords Ectomycorrhiza $\cdot$ Heavy metal tolerance . Josephine ophiolite $\cdot$ Non-metric multidimensional scaling $\cdot$ Oaks $\cdot$ Quercus garryana $\cdot$ Serpentine

\section{Introduction}

The ectomycorrhizal community of Quercus garryana Dougl. ex Hook. exhibits rich biodiversity (Valentine et al. 2004). On alluvial soils in Southern Oregon, roots formed mycorrhizas with 40 fungal species; the most common were Cenococcum geophilum and Tuber candidum. Mycorrhizas mediate the contact between plant and soil through the interface of the ectomycorrhizal mantle, a sheath of fungal tissue that surrounds root tips. If soil composition influences ectomycorrhizal fungi, then serpentine soils may select for different fungi. In order to evaluate the role of soil composition on mycorrhizal communities, we sought a soil type that differed significantly from the metamorphic and alluvial soils that make up much of Q. garryana habitat.

Serpentine soils, rich in iron, magnesium, and heavy metals such as chromium and nickel, have a suite of soil properties that differ from nonserpentine soils derived from metasedimentary rocks (Brooks 
1987; Alexander 1988; O’Hanley 1996; Lee et al. 2001; Oze et al. 2004). The effect of these soil differences is a change in vegetation density and in woody plant species (Kruckeberg 2006). Although edaphic factors are widely recognized for their importance in the ecology and evolution of serpentine plants, the effects of ultramafic soils on ectomycorrhizas and on the role of mycorrhizas in serpentine tolerance and sensitivity is often overlooked (Kruckeberg 1984, 1986, 1992; Brooks 1987; Brady et al. 2005; Grace et al. 2007). For example, a study looking at the physiological adaptation of Ponderosa pines to serpentine soils over 20 years did not consider the development of a mycorrhizal community (Wright 2007). However, Alexander et al. (2007) recognized the need to include a mycorrhizal component in studies of the adaptation of plants to serpentine soils.

Moser et al. (2005) compared the diversity of ectomycorrhizas associated with Q. garryana at three sites with paired serpentine and nonserpentine soils. Ectomycorrhizas were abundant at all sites; communities on serpentine soils were similar in morphotype richness to those on neighboring nonserpentine soils with no single fungal morphotype dominating on either soil type. These results were unexpected because fungi take up heavy metals and because some fungi have ecotypes or strains with tolerance to heavy metals (Gadd and deRome 1988; Gadd 1993; Galli et al. 1994; Jentschke and Godbold 2000; Meharg and Cairney 2000; Panaccione et al. 2001; Colpaert et al. 2000). Possible explanations for the finding of similar ectomycorrhizal communities on serpentine and nonserpentine soils by Moser et al. (2005) include too great a distance between sites, the weakly serpentinic composition of two of the sites, and lack of molecular confirmation of morphotype identity. Ectomycorrhizas on paired serpentine and nonserpentine sites ( $1 \mathrm{~km}$ apart) were more similar to each other than to those on distantly separated serpentine sites (up to $50 \mathrm{~km}$ apart). Only one serpentine site had levels of heavy metals greater than $1000 \mu \mathrm{g} / \mathrm{g}$ and a magnesium-to-calcium ratio greater than two (Moser et al. 2005).

Here we studied the ectomycorrhizas of $Q$. garryana on serpentine in ways that represent several advances. First, we sampled mycorrhizas at strongly serpentinic sites with high concentrations of chromium and nickel within $26 \mathrm{~km}$ of each other (Garcia 1979; Ramp and Peterson 1979; Harper 2003;
Alexander et al. 2007). Second, we added molecular methods to identify ectomycorrhizal fungi. Third, we used ordination methods rather than pairwise similarity indices to compare communities. We test the hypotheses that mycorrhizal fungi would differ on serpentine soils, that they would be sparser in the drier soils, have less diversity, and be characterized by a unique set of serpentine-specific fungi.

\section{Materials and methods}

Study sites

We selected two sites in the Klamath-Siskiyou Mountains (Josephine County, OR, USA), each with Q. garryana Dougl. ex Hook. (Oregon white oak) growing on serpentine and nonserpentine soils in relatively close proximity (Ramp and Peterson 1979; Alexander et al. 2007): Waldo Mountain, south of Cave Junction, OR, USA on the Rattlesnake Creek Terrane (serpentine $-42^{\circ} 03^{\prime} \mathrm{N}, 123^{\circ} 39^{\prime} \mathrm{W}$, elevation $640 \mathrm{~m}$; nonserpentine $-42^{\circ} 02^{\prime} \mathrm{N} 123^{\circ} 39^{\prime} \mathrm{W}$, elevation $720 \mathrm{~m}, 1.4 \mathrm{~km}$ apart) and Eight Dollar Mountain, west of Selma, OR, USA on the Josephine ophiolite (serpentine $-42^{\circ} 17^{\prime} \mathrm{N} 123^{\circ} 41^{\prime} \mathrm{W}$, elevation $460 \mathrm{~m}$; nonserpentine $-42^{\circ} 17^{\prime} \mathrm{N} 123^{\circ} 42^{\prime} \mathrm{W}$, elevation $420 \mathrm{~m}, 2.1 \mathrm{~km}$ apart). The Waldo Mountain and Eight Dollar Mountain sites were $26 \mathrm{~km}$ apart. On serpentine soil at Eight Dollar Mountain, the oak was Q. garryana var. breweri (Engelm.) Jepson, the shrubby Brewer's oak with many stems about $2 \mathrm{~m}$ tall. At all other sites, the Oregon white oak was the tree form $Q$. garryana var. garryana, with single stems up to $7 \mathrm{~m}$ tall, although there was some overlap of form between the two varieties. At both sites, identity of serpentine and nonserpentine soils was confirmed by visual appraisal of rock characteristics and by soil analyses.

\section{Sampling}

Root samples for mycorrhizas were taken in February 2004. Each sample unit consisted of a total volume of 200 to $600 \mathrm{~mL}$ pooled from four soil cores from one tree taken along radii in the four cardinal directions at the canopy drip line. Soil samples were extracted with a soil corer $(2.5 \mathrm{~cm}$ diameter $\times 25 \mathrm{~cm}$ long) from the upper $15-20 \mathrm{~cm}$ of mineral soil. Six trees, at least 
$10 \mathrm{~m}$ apart, were sampled on each soil type at both sites. Soil samples were washed and sieved. And the ectomycorrhizal roots picked out under a dissecting microscope at $\times 10$.

For analyses of soil composition, an additional four soil cores per tree were collected from each soil type at both sites. Composite samples were dried, ground, and analyzed at DANR Analytical Laboratory, University of California, Davis (http://danranlab.ucanr. org). Methods of elemental analyses followed those in Moser et al. (2005).

\section{Morphotyping}

All mycorrhizas were sorted by morphotype, a suite of characters including color, branching pattern, emanating hyphae, and mantle peels (Agerer 1991; Valentine et al. 2004; Moser et al. 2005). To quantify mycorrhiza abundance, we counted individual mycorrhizal root tips. We selected the most abundant mycorrhizal morphotypes from both soil types at each site for molecular analysis.

\section{Molecular methods}

Molecular data were obtained by sequencing of the internal transcribed spacer (ITS) region, including ITS1, the $5.8 \mathrm{~S}$ ribosomal DNA gene and ITS2. DNA was extracted from ectomycorrhizas in cetyl trimethylammonium bromide with chloroform and amplified in polymerase chain reactions (PCR) with fungal specific primers ITS1F and ITS4 (White et al. 1990, Gardes and Bruns 1993, Bruns et al. 1998). Selected PCR products were cleaned in Montage PCR Centrifugal Filter Devices (Millipore Corporation), prepared for sequencing with BigDye Terminator Ready Reaction
Mix and sequenced by an ABI 310 Genetic Analyzer (Applied Biosystems). Sequences were edited with Chromas 1.45 (McCarthy 1998) and compared to other fungal DNA sequences in GenBank with Basic Local Alignment Search Tool (BLAST; Altschul et al. 1990). Identifications were based on strength of match, similarity over the entire fragment length, consistency of matches, the pattern of top matches to vouchered specimens, and dissimilarity to other genera. Sequences were aligned and compared to each other in ClustalX to determine whether multiple species were present (Thompson et al. 1997)

\section{Statistics}

Soil properties were compared by one-way analysis of variance (ANOVA) with Minitab Release 15; the numbers of tips per sample, number of tips per soil volume, or fraction of the total number of tips for that sample were compared by two-way ANOVA. Coefficients of dispersion were calculated for tip abundance of the six most common species (Sokal and Rohlf 1996).

Similarities among samples were investigated on species abundance measured as tips/sample, tips/L, and on the proportion of each species as a fraction of the total mycorrhizal root tips from each sample using nonmetric multidimensional scaling (NMS) in PCORD 5 (McCune and Mefford 1999; McCune and Grace 2002). Distance measures were Jaccard (presence/ absence) and Sørensen (abundance values). To minimize stress and reduce noise, datasets were tested as raw data; modified with sequential elimination of species present in one to four samples and with elimination of Cenococcum, the only outlier species; and with proportional abundance data transformed to arcsine squareroots and tip count data to logarithms

Table 1 Soil analyses for serpentine (Serp) and nonserpentine (Non) soils (four samples each) at Waldo Mountain (WM) at and Eight Dollar Mountain (EDM) in southwestern Oregon, USA

\begin{tabular}{llllllllllll}
\hline Soil & Site & pH & N \% & C \% & P ppm & $\begin{array}{l}\text { X-Ca } \\
\text { meq/100 g }\end{array}$ & $\begin{array}{l}\text { X-Mg } \\
\text { meq/100 g }\end{array}$ & Mg:Ca & Fe ppm & Cr ppm & Ni ppm \\
\hline Serp & WM & 5.7 & 0.23 & 4.4 & 11.3 & 11.5 & 24.0 & 2.1 & 15.45 & 1162.3 & 1581 \\
Serp & EDM & 6.08 & 0.19 & 3.42 & 2.22 & 4.2 & 11.0 & 2.6 & 7.2 & 1878.5 & 3036 \\
Mean & (SD) & $5.9(0.3)^{\mathrm{a}}$ & $0.2(0.1)$ & $3.8(1.0)$ & $5.9(6.5)$ & $7.1(4.8)$ & $16.2(8.6)^{\mathrm{a}}$ & $2.3(0.4)^{\mathrm{a}}$ & $10.5(5.4)$ & $1592(489)^{\mathrm{a}}$ & $2454(802)^{\mathrm{a}}$ \\
Non & WM & 5.35 & 0.3 & 5.06 & 2.7 & 13.2 & 8.6 & 0.7 & 5.5 & 227 & 246 \\
Non & EDM & 5.1 & 0.14 & 2.75 & 6.25 & 9.8 & 4.8 & 0.5 & 5.65 & 112 & 77 \\
Mean & $(\mathrm{SD})$ & $5.2(0.1)^{\mathrm{a}}$ & $0.2(0.1)$ & $4.5(2.1)$ & $4.5(2.1)$ & $11.5(2.3)$ & $6.7(2.4)^{\mathrm{a}}$ & $0.6(0.1)^{\mathrm{a}}$ & $5.6(0.1)$ & $169(67)^{\mathrm{a}}$ & $161(99)^{\mathrm{a}}$ \\
\hline
\end{tabular}

${ }^{\text {a }}$ Soil characteristics within a column differed significantly between soil types using one-way ANOVA $(P>0.05)$. 
Table 2 Abundance of ectomycorrhizas (EMs) as measured by number of ectomycorrhizal root tips per liter of soil under Quercus garryana in serpentine and nonserpentine soils at Waldo Mountain (WM) and Eight Dollar Mountain (EDM), OR, USA

\begin{tabular}{|c|c|c|c|c|c|c|}
\hline \multirow[t]{2}{*}{ Site } & \multicolumn{3}{|l|}{ Nonserpentine } & \multicolumn{3}{|l|}{ Serpentine } \\
\hline & Mean (se) tips/L & Range & Total EMs & Mean (se) tips/L & Range & Total Ems \\
\hline WM & $653(196)$ & $113-1488$ & 971 & $409(150)$ & $83-1091$ & 1088 \\
\hline EDM & $360(76)$ & $74-686$ & 851 & $630(257)$ & $140-1716$ & 926 \\
\hline Both & 507 (110) & & 1822 & $520(498)$ & & 2014 \\
\hline
\end{tabular}

For each site and soil type, $n=6$. Differences in abundance of ectomycorrhizas between soil types were not significant using two-way ANOVA $(P>0.05)$.

(McCune and Grace 2002). We analyzed a matrix of 18 mycorrhiza species from 24 plots (Supplement 1). NMS was performed with 50 runs of real data along with 100 runs with randomized data for a Monte Carlo test of significance. Groups were compared using multi-response permutation procedures (MRPP) in PC-ORD 5 to determine the significance of differences (McCune and Mefford 1999; McCune and Grace 2002).

\section{Results}

\section{Soil characteristics}

At both the Eight Dollar Mountain and Waldo Mountain sites, the $\mathrm{pH}$, the concentrations of $\mathrm{Mg}$, $\mathrm{Cr}$, and $\mathrm{Ni}$, and the $\mathrm{Mg}: \mathrm{Ca}$ ratio were significantly higher on serpentine than on nonserpentine soils (Table 1). Iron was significantly higher on serpentine

Table 3 Identification of ectomycorrhizas from Quercus garryana in southwestern Oregon, based on BLAST matches from GenBank

\begin{tabular}{|c|c|c|c|c|c|c|c|c|}
\hline Concensus taxon & $\begin{array}{l}\text { GenBank } \\
\text { accession }\end{array}$ & Soil & $\begin{array}{l}\text { Length } \\
\text { (bp) }\end{array}$ & Closest vouchered BLAST match & $\begin{array}{l}\text { Max } \\
\text { score }\end{array}$ & $\begin{array}{l}\text { Query } \\
\text { coverage (\%) }\end{array}$ & E value & Max ident \\
\hline Boletus sp. & EU018562 & $\mathrm{N}$ & 623 & Boletus pseudoregius AY680996 & 838 & 96 & 0.0 & $91 \%$ \\
\hline Cortinarius sp. & EU018564 & $\mathrm{S}$ & 409 & Cortinarius parvannulatus AY669664 & 419 & 91 & $4 \mathrm{e}-114$ & $87 \%$ \\
\hline Genea sp. & EU018565 & $\mathrm{N}$ & 368 & Genea sp. AY920529 & 444 & 98 & $9 \mathrm{e}-122$ & $89 \%$ \\
\hline Genea sp. & EU018566 & $\mathrm{S}$ & 674 & Genea harknessii DQ218292 & 755 & 99 & 0.0 & $84 \%$ \\
\hline Gilkeya sp. & EU018567 & $\mathrm{S}$ & 533 & Gilkeya compacta DQ206862 & 937 & 100 & 0.0 & $98 \%$ \\
\hline Gilkeya sp. & EU018568 & $\mathrm{S}$ & 403 & Gilkeya compacta DQ206862 & 652 & 97 & 0.0 & $97 \%$ \\
\hline Inocybe sp. & EU018569 & $\mathrm{S}$ & 330 & Inocybe sp. DQ974804 & 329 & 100 & $4 \mathrm{e}-87$ & $83 \%$ \\
\hline Inocybe sp. & EU018570 & $\mathrm{S}$ & 597 & Inocybe inodora AM882901 & 641 & 89 & $1 \mathrm{e}-180$ & $88 \%$ \\
\hline Inocybe sp. & EU018572 & $\mathrm{N}$ & 444 & Inocybe subnudipes AM882809 & 511 & 95 & $9 \mathrm{e}-142$ & $87 \%$ \\
\hline Lactarius sp. & EU018573 & $\mathrm{N}$ & 555 & Lactarius substriatus DQ974746 & 872 & 98 & 0.0 & $95 \%$ \\
\hline Otidea sp. & EU018574 & $\mathrm{N}$ & 552 & Otidea umbrina DQ974738 & 906 & 97 & 0.0 & $97 \%$ \\
\hline Russula sp. & EU018575 & $\mathrm{S}$ & 130 & Russula delica AY061671 & 219 & 99 & $2 \mathrm{e}-54$ & $97 \%$ \\
\hline Sebacina sp. & EU018576 & $\mathrm{S}$ & 684 & Sebacina sp. DQ974768 & 706 & 72 & 0.0 & $94 \%$ \\
\hline Sebacina sp. & EU018577 & $\mathrm{S}$ & 575 & Sebacina sp. DQ974768 & 870 & 99 & 0.0 & $94 \%$ \\
\hline Sebacina sp. & EU018578 & $\mathrm{S}$ & 460 & Sebacina sp. DQ974770 & 500 & 96 & $2 \mathrm{e}-138$ & $87 \%$ \\
\hline Sebacina sp. & EU018579 & $\mathrm{S}$ & 416 & Sebacina sp. DQ974770 & 434 & 97 & $2 \mathrm{e}-118$ & $86 \%$ \\
\hline Sebacina sp. & EU018580 & $\mathrm{S}$ & 454 & Sebacina sp. DQ974770 & 605 & 97 & $5 e-170$ & $90 \%$ \\
\hline Sebacina sp. & EU018581 & $\mathrm{N}$ & 568 & Sebacina sp. DQ974768 & 765 & 99 & 0.0 & $90 \%$ \\
\hline Sebacina sp. & EU018582 & $\mathrm{N}$ & 679 & Sebacina sp. DQ974768 & 729 & 84 & 0.0 & $89 \%$ \\
\hline Tomentella $\mathrm{sp}$. & EU018583 & $\mathrm{N}$ & 609 & Tomentella sp. U83482 & 899 & 99 & 0.0 & $93 \%$ \\
\hline Tomentella $\mathrm{sp}$. & EU018585 & $\mathrm{S}$ & 442 & Tomentella sp. U92537 & 630 & 100 & $1 \mathrm{e}-177$ & $93 \%$ \\
\hline Tomentella $\mathrm{sp}$. & EU018586 & $\mathrm{N}$ & 431 & Tomentella sp. AJ534913 & 551 & 99 & $1 \mathrm{e}-153$ & $90 \%$ \\
\hline Tomentella $\mathrm{sp}$. & EU018587 & $\mathrm{N}$ & 263 & Tomentella stuposa AY010277 & 372 & 97 & $3 e-100$ & $92 \%$ \\
\hline Tuber candidum & EU018589 & $\mathrm{N}$ & 637 & Tuber candidum AY830856 & 987 & 99 & 0.0 & $95 \%$ \\
\hline Tuber candidum & EU018590 & $\mathrm{S}$ & 685 & Tuber candidum AY830856 & 881 & 94 & 0.0 & $91 \%$ \\
\hline Tuber whetstonense & EU018592 & $\mathrm{S}$ & 587 & Tuber whetstonense AY830855 & 829 & 100 & 0.0 & $97 \%$ \\
\hline
\end{tabular}

Soil type: N, nonserpentine; S, serpentine. 
soils at Waldo Mountain, but not at Eight Dollar Mountain. Exchangeable $\mathrm{Ca}$ was slightly higher on nonserpentine soils, but the difference from nonserpentine soils was not significant. The significantly higher exchangeable $\mathrm{Mg}$ on serpentine soils contributed to the higher $\mathrm{Mg} / \mathrm{Ca}$ ratio. Serpentine and nonserpentine soils did not differ significantly in $\mathrm{C}$, $\mathrm{N}$, or P.

\section{Ectomycorrhiza abundance}

In single soil samples, total numbers of ectomycorrhizas ranged from 140 to 1716 ectomycorrhizal root tips per liter of soil (Table 2). Mean differences in abundance of ectomycorrhizas on serpentine and nonserpentine soils were not significant.

\section{Classification of ectomycorrhizas}

DNA extractions from 32 morphotype collections yielded sequence data of usable quality with sequence matches ranging in strength from $83 \%$ to $98 \%$. Based on BLAST results, 13 species of ectomycorrhizal fungi were identified (Table 3). For example, a $623 \mathrm{bp}$ signal with no base pair ambiguities closely matched 17 sequences in the genus Boletus, without a consistent match to any single species. The shortest sequence, a $130 \mathrm{bp}$ fragment matching only Russula delica, was entirely in the highly variable ITS1 region with a maximum identity match of $97 \%$. Alignments with ClustalX separated Tuber into two phyletic groups. The genus Tuber includes two distinct clades, distinguishable by morphology of their ectomycor-

Table 4 Morphotype descriptions of ectomycorrhizas of Quercus garryana from Southwestern Oregon

\begin{tabular}{|c|c|c|}
\hline Concensus taxon & Soil & Morphotype \\
\hline Boletus sp. Fig. 8 & $\mathrm{~N}$ & $\begin{array}{l}\text { Tan; monopodial pyramidal, bent and tortuous; smooth; few rhizomorphs; few white hyphae; } \\
\text { i: nets, o: netp }\end{array}$ \\
\hline Cortinarius sp. Fig. 19 & $\mathrm{~N}, \mathrm{~S}$ & White; long white thick hyphal fans; monopodial pyramidal, bent; smooth; i: nets, o: netp \\
\hline Genea sp. Figs. 5, 6, 7 & $\mathrm{~N}, \mathrm{~S}$ & $\begin{array}{l}\text { Dark red-brown, lighter red-brown tips; smooth; monopodial pyramidal; straight brown hyphae; } \\
\text { i: nets, o: reg }\end{array}$ \\
\hline Gilkeya compacta Figs. 11, 12 & $\mathrm{~S}$ & $\begin{array}{l}\text { Tan; short dichotomous, pale tips; smooth, coralloid and straight; sparse white hyphae; } \\
\text { i: nets, o: non }\end{array}$ \\
\hline Inocybe sp. Fig. 18 & $\mathrm{~N}, \mathrm{~S}$ & $\begin{array}{l}\text { White; tan base; smooth; monopodial pinnate and pyramidal, club-shaped tips, coralloid } \\
\text { branching; short white hyphae; isolated or cottony; i: netp, o: nets }\end{array}$ \\
\hline Lactarius sp. Figs. 14, 15 & $\mathrm{~N}, \mathrm{~S}$ & $\begin{array}{l}\text { Yellow-tan; smooth to grainy; monopodial pyramidal, irregular branching, tortuous; } \\
\text { white hyphae; i: int, o: netp or nets. }\end{array}$ \\
\hline Otidea sp. Fig. 13 & $\mathrm{~N}$ & Yellow-tan; smooth; monopodial pyramidal, straight; white cottony hyphae; o: netp \\
\hline Russula sp. Fig. 16 & $\mathrm{~N}, \mathrm{~S}$ & Brown to light brown; reddish layer under mantle; cystidia flask-shaped; i:int, o: nets. \\
\hline Sebacina sp., Fig. 17 & $\mathrm{~N}, \mathrm{~S}$ & $\begin{array}{l}\text { Yellow-white over gray-tan base; monopodial pinnate or pyramidal, tortuous; tufts of cottony } \\
\text { white hyphae; i: int, o: nets. }\end{array}$ \\
\hline Tomentella sp. Figs. 3, 4 & $\mathrm{~N}, \mathrm{~S}$ & $\begin{array}{l}\text { Black, dark brown; often with brown tips; monopodial pinnate, tortuous; bent; grainy; } \\
\text { visible mantle; pale hyphae; i: nets netp; o: non to reg }\end{array}$ \\
\hline Tuber candidum Figs. 9, 10 & $\mathrm{~N}, \mathrm{~S}$ & $\begin{array}{l}\text { Orange-tan to brassy tan, often with pale tips; monopodial pinnate or pyramidal, tortuous, } \\
\text { bent; smooth; few short white hyphae; i: nets, o: int to non. }\end{array}$ \\
\hline Tuber whetstonense & $\mathrm{N}, \mathrm{S}$ & $\begin{array}{l}\text { Orange-tan to brassy, often with pale tips; monopodial pinnate or pyramidal, tortuous, } \\
\text { bent; smooth; some with cystidia; i: nets, o: int to non. }\end{array}$ \\
\hline Cenococcum geophilum Figs. 1, 2 & $\mathrm{~N}, \mathrm{~S}$ & Black; grainy; most unbranched; straight and tortuous; long black hyphae; star syn \\
\hline Unknown 1 & $\mathrm{~N}$ & Black with jade green patches; nets \\
\hline Unknown 2 & $\mathrm{~S}$ & Brown; bifurcate; cystidial; i: netp to nets, o: reg \\
\hline Unknown 3 & $\mathrm{~S}$ & Brown; with extensive hyphae; i: netp, o: nets \\
\hline Unknown 4 & $\mathrm{~S}$ & Brown; surface rough; i: nets, o: reg \\
\hline Unknown 5, Fig. 20 & $\mathrm{~S}$ & White; thick bifurcated tips; white rhizomorphs; i: nets, o: netp \\
\hline
\end{tabular}

Soil types: $S$ Serpentine, $N$ nonserpentine; mantle types: $i$ inner mantle, $o$ outer mantle, netp net prosenchyma, nets net synenchyma, int interlocking irregular synenchyma, non non-interlocking irregular synenchyma, reg regular synenchyma, syn synenchyma (Agerer 1991). 
rhizas and by large differences in their ITS sequences (Frank et al. 2006a). These were separated by morphotype and identified to species, T. candidum and $T$. whetstonense.

All tips were sorted into morphotypes based on microscopic characters (Table 4).

Black morphotypes $C$. geophilum was identified by the black mantle with star-patterned synenchyma and stiff, black, often angular emanating hyphae (Figs. 1, 2). Tomentella sp. varied from black to dark brown with flexible, pale brown emanating hyphae (Figs. 3, 4). One black morphotype, Unknown black-green (U-1) from one sample did not fit either pattern.

Brown morphotypes Genea sp. mycorrhizas were dark red-brown with slightly lighter red-brown tips and pale brown hyphae (Table 4, Fig. 5). An outer mantle of regular synenchyma was often visible under the dissecting microscope (Figs. 6, 7). Three brown morphotypes lacked the red-brown tips or outer mantle that defined Genea. The most frequent of these was unknown brown rough (U-4); others were unknown brown hyphal (U-3) and unknown brown cystidial (U-2).

Tan morphotypes Boletus sp. lacked pale tips and appeared slightly more yellow than Tuber morphotypes (Fig. 8). T. candidum (Fig. 9) and T. whetstonense were rusty or orange-tan color with paler tips; older Tuber mycorrhizas lacked pale tips. The inner mantle was net synenchyma; the outer mantle graded from interlocking to non-interlocking synenchyma (Fig. 10). Cystidia were present on some tan mycorrhizas indicating T. whetstonense. Gilkeya compacta had bi- and trifurcate tips and an outer mantle pattern of interlocking synenchyma that was visible under the dissecting microscope (Figs. 11, 12). Otidia sp. was yellow-tan with pale emanating hyphae (Fig. 13). Lactarius sp. (Figs. 14, 15) and Russula sp. (Fig. 16) were cystidial.

Pale tan to white morphotypes Sebacina sp. varied from tan-white to gray-tan (Fig. 17). Inocybe sp. varied from pale tan to white with thicker tips (Fig. 18). Cortinarius was similarly tan, but with white rhizomorphs (Fig. 19). Unknown white bifurcate (U-5, Fig. 20) resembled the color and thickness of Inocybe, but none of the sequenced Inocybe mycorrhizas demonstrated this bifurcate pattern.
Fig. 1 Ectomycorrhizas of Q. garryana on serpentine and nonserpentine soils. C. geophilum with stiff black emanating hyphae

Fig. 2 Ectomycorrhizas of Q. garryana on serpentine and nonserpentine soils. C. geophilum mantle, star synenchyma

Fig. 3 Ectomycorrhizas of Q. garryana on serpentine and nonserpentine soils. Tomentella sp., pale soft emanating hyphae Fig. 4 Ectomycorrhizas of Q. garryana on serpentine and nonserpentine soils. Tomentella sp. lacking hyphae

Fig. 5 Ectomycorrhizas of Q. garryana on serpentine and nonserpentine soils. Genea sp., red-brown, pale hyphae

Fig. 6 Ectomycorrhizas of $Q$. garryana on serpentine and nonserpentine soils. Ge. sp. inner mantle, net synenchyma

Fig. 7 Ectomycorrhizas of Q. garryana on serpentine and nonserpentine soils. Ge. sp. outer mantle, regular synenchyma

Fig. 8 Ectomycorrhizas of Q. garryana on serpentine and nonserpentine soils. Boletus sp., tan

Fig. 9 Ectomycorrhizas of Q. garryana on serpentine and nonserpentine soils. T. candidum, orange-tan, pale tips

Fig. 10 Ectomycorrhizas of Q. garryana on serpentine and nonserpentine soils. T. candidum outer mantle, interlocking and non-interlocking regular synenchyma

Fig. 11 Ectomycorrhizas of Q. garryana on serpentine and nonserpentine soils. G. compacta, bifurcate golden tan tips

Fig. 12 Ectomycorrhizas of $Q$. garryana on serpentine and nonserpentine soils. G. compacta outer mantle, thin-walled regular synenchyma

Fig. 13 Ectomycorrhizas of $Q$. garryana on serpentine and nonserpentine soils. Otidea sp. yellow-tan, emanating hyphae

Fig. 14 Ectomycorrhizas of Q. garryana on serpentine and nonserpentine soils. Lactarius sp., brown-tan, pale tips

Fig. 15 Ectomycorrhizas of Q. garryana on serpentine and nonserpentine soils. Lactarius sp., cystidia

Fig. 16 Ectomycorrhizas of Q. garryana on serpentine and nonserpentine soils. Russula sp., brown-tan

Fig. 17 Ectomycorrhizas of Q. garryana on serpentine and nonserpentine soils. Sebacina sp., gray-tan cluster

Fig. 18 Ectomycorrhizas of Q. garryana on serpentine and nonserpentine soils. Inocybe sp., white to light tan

Fig. 19 Ectomycorrhizas of Q. garryana on serpentine and nonserpentine soils. Cortinarius sp., tan with white rhizomorphs

Fig. 20 Ectomycorrhizas of Q. garryana on serpentine and nonserpentine soils. Unknown-5, white bifurcate

Abundance and frequency of ectomycorrhizal species

Of the 18 species only six, all identified by DNA sequences, occurred in more than five samples and in both soil types (Fig. 21, Table 5, Supplement 1). Nearly $80 \%$ of all mycorrhizal tips fit into these categories. The proportions of each species did not differ significantly among soil types or sites (ANOVA, $P>0.05$ ) when calculated as number of tips per sample, number of tips per soil volume or as fraction of the total number of tips for that sample. The largest fraction was of T. candidum, followed by 

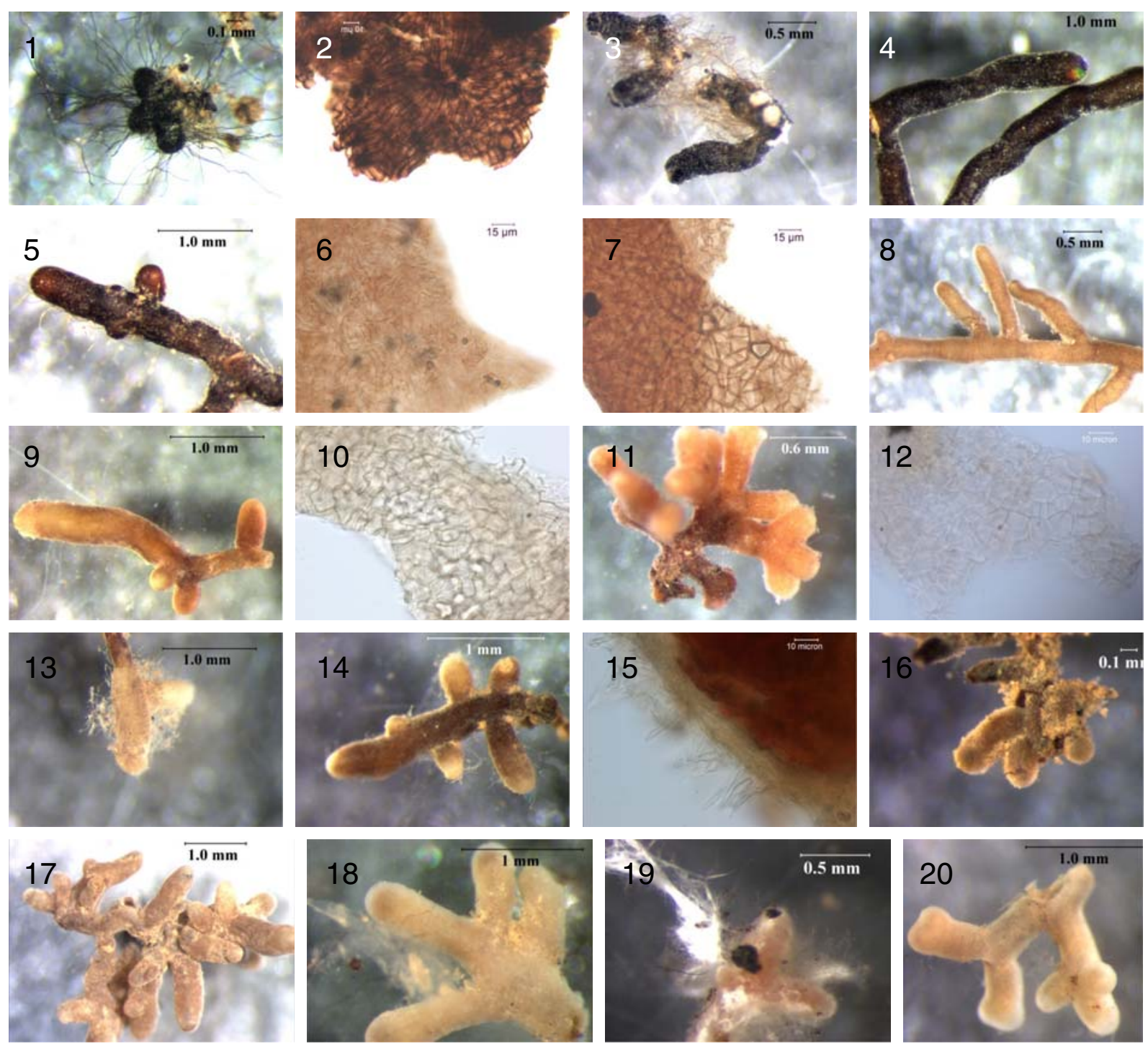

C. geophilum, Tomentella sp., Sebacina sp., Genea sp., and Inocybe sp. (Fig. 21). Coefficients of dispersion were greater than three for all six of the most common species indicating a clumped, nonrandom distribution (Sokal and Rohlf 1996).

The six most common species occurred on both serpentine and nonserpentine soils at both sites. Among the less frequent species, Russula sp. and Lactarius sp. occurred on both soil types; Boletus sp., Otidea sp. and unknown-1 on nonserpentine only; and G. compacta and unknown-4 on serpentine only and at both sites. These were abundant in one or few samples.

Based on similarities calculated using the Sørensen index in NMS, no distinct patterns of mycorrhizal communities were detected among the sites (Waldo Mountain and Eight Dollar Mountain) and soil types (serpentine and nonserpentine; Fig. 22). Mycorrhizal assemblages overlapped in ordination space so that no pattern of distinct groups by site or soil type emerged in any of the ordinations. The same patterns of randomness were found when species were measured by number of tips per sample, by number of tips per soil volume, and by percent composition. The random intermixing of samples occurred whether the ordination included entire dataset, the dataset modified to eliminate species found in fewer than four plots, or the $\log$ transform of entire dataset. The only species outlier was Cenococcum, which was present in the 


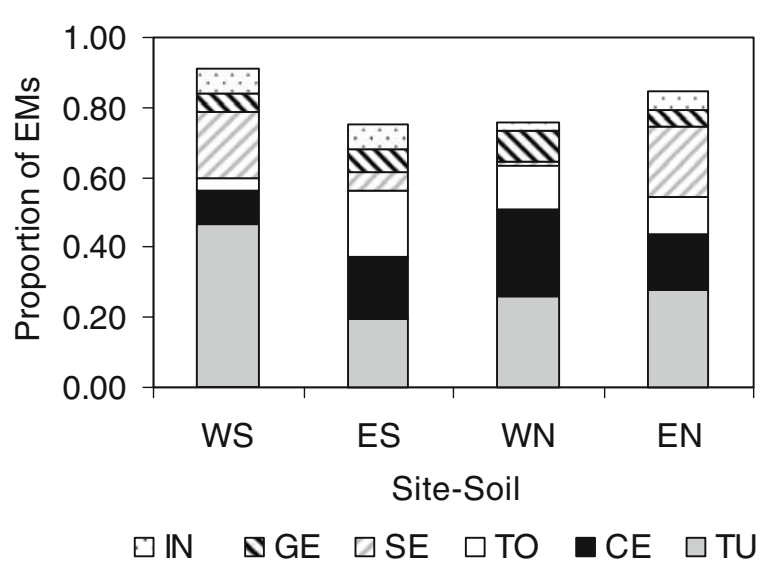

Fig. 21 Relative abundance of the most common ectomycorrhizas (EMs) as a proportion of total EMs on serpentine (S) and nonserpentine $(\mathrm{N})$ soils at Waldo Mountain (W) and Eight Dollar Mountain (E) in Southwestern Oregon. TU, T. candidum, CE, C. geophilum, TO, Tomentella sp., SE, Sebacina sp., $G E$, Genea sp., and IN, Inocybe sp

most samples. Removing Cenococcum from the dataset also did not change the overlap of communities. One sample (on serpentine at Waldo Mountain) had only one species, $T$. candidum and that was not plotted by the ordination process (Fig. 22). The one pattern that emerged was that assemblages on serpentine soils were less similar to each other (average distance 0.82)

Table 5 Frequency of occurrence of mycorrhizal species on serpentine $(\mathrm{S})$ and nonserpentine $(\mathrm{N})$ soils at Waldo Mountain (W) and Eight Dollar Mountain (E), six trees per soil type at each site

\begin{tabular}{llllll}
\hline Ectomycorrhiza & ES & WS & EN & WN & All \\
\hline Tuber candidum & 5 & 6 & 6 & 6 & 23 \\
Cenococcum geophilum & 6 & 3 & 6 & 5 & 20 \\
Tomentella sp. & 3 & 1 & 5 & 5 & 14 \\
Genea sp. & 2 & 2 & 4 & 5 & 13 \\
Inocybe sp. & 3 & 2 & 2 & 4 & 11 \\
Sebacina sp. & 3 & 2 & 5 & 1 & 11 \\
Cortinarius & 2 & 0 & 1 & 2 & 5 \\
Tuber whetstonense & 0 & 1 & 0 & 3 & 4 \\
Gilkeya compacta & 2 & 1 & 0 & 0 & 3 \\
Lactarius sp. & 1 & 0 & 1 & 1 & 3 \\
Russula sp. & 1 & 1 & 0 & 1 & 3 \\
Unknown 4 & 1 & 2 & 0 & 0 & 3 \\
Otidea sp. & 0 & 0 & 0 & 1 & 1 \\
Unknown 1 & 0 & 0 & 1 & 0 & 1 \\
Unknown 2 & 1 & 0 & 0 & 0 & 1 \\
Unknown 3 & 1 & 0 & 0 & 0 & 1 \\
Unknown 5 & 0 & 1 & 0 & 0 & 1 \\
Boletus sp. & 0 & 0 & 0 & 1 & 1 \\
\hline
\end{tabular}

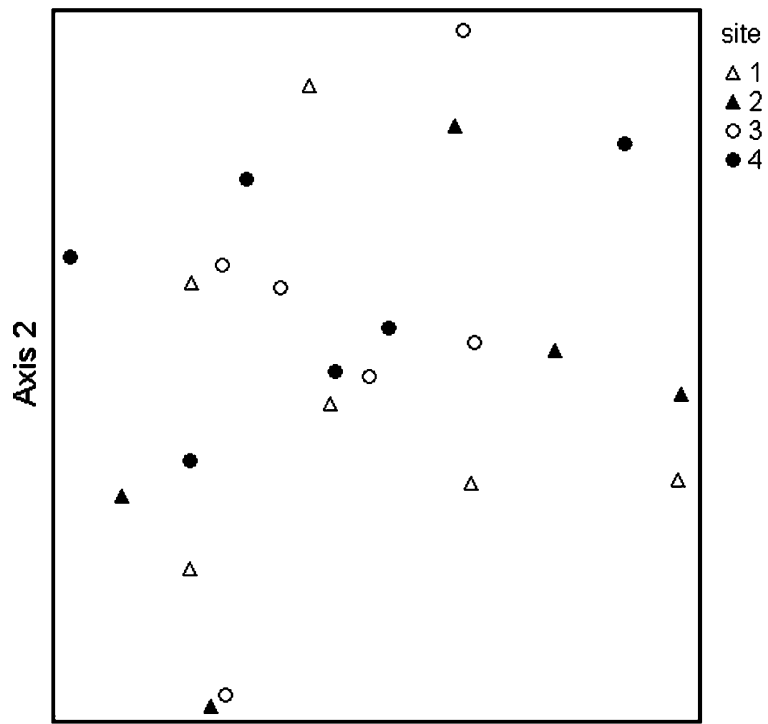

Axis 1

Fig. 22 NMS ordination, using Sørensen distance, of ectomycorrhizas on serpentine (solid symbols) and nonserpentine (open symbols) soils at Waldo Mountain (triangles) and Eight Dollar Mountain (circles) in Southwestern Oregon. The data were counts of EMs per sample. The samples intermix with no particular pattern related to soil type or site. Serpentine samples were less similar and more widely spread in ordination space than nonserpentine samples

and spread over a larger area of ordination space than nonserpentine assemblages (average distance 0.71). Based on MRPP using the same index of similarity as for NMS, the distances between groups (serpentine and nonserpentine) were not significantly different from random $(A=0.00075, P=0.41)$.

\section{Discussion}

The serpentine sites at both Eight Dollar Mountain and Waldo Mountain were strongly serpentinic with higher levels of $\mathrm{Mg}, \mathrm{Cr}$, and Ni. These sites provide extreme differences between serpentine and nonserpentine soils (Brooks 1987; Alexander 1988; Alexander et al. 2007).

The most abundant and most frequent species of ectomycorrhizas associated with oaks on serpentine soils were the very common fungal species associated with oaks on all soils world wide: $C$. geophilum, an asexual Ascomycota with sclerotia; hypogeous Ascomycota (Tuber, Genea, Gilkeya, and other Pezizales); crust-forming resupinate Basidiomycota (Sebacina 
and Tomentella); and fleshy Basidiomycota (Russula, Boletus, Inocybe, and Cortinarius; Cairney and Chambers 1999; Avis et al. 2003; Valentine et al. 2004; Moser et al. 2005; Richard et al. 2005; Walker et al. 2005; Frank et al. 2006b).

Serpentine soils supported extensive mycorrhizal communities. Serpentine mycorrhizal communities were not dominated by a single species nor were they distinguishable as groups of similar species distinct from nonserpentine mycorrhizal communities. Variability of ectomycorrhizal communities was as great between sites (Eight Dollar Mountain versus Waldo Mountain) as between soil types (serpentine versus nonserpentine) at each site.

Maas and Stuntz (1969) compared epigeous fungi under conifers on serpentine and nonserpentine soils in Washington. Several genera in the Basidiomycota, including Inocybe and Suillus, were found on both soil types. Only two hypogeous genera were reported (Rhizopogon and Thaxterogaster). Of 13 Ascomycota, only three were found on serpentine soils; these did not include Tuber or Genea. They did not examine ectomycorrhizas directly. Fruiting bodies and mycorrhizas are overlapping sets of species. The correlation between fruiting body abundance and mycorrhizal abundance is generally poor, especially where sampling is done only once and where fruiting is erratic due to dry soils (Horton and Bruns 2001; Taylor 2002).

The common ectomycorrhizal species with $Q$. garryana were similar on serpentine and nonserpentine soils. The abundances and proportions of epigeous, hypogeous, and resupinate fungal species, along with Cenococcum, were similar in these diverse soil types. Occasionally, individual epigeous species and hypogeous species occurred on one or the other soil types, but not in a widely repeated pattern across the landscape.

There may be uncommon species or ecotypes that prefer or avoid serpentine. Isolates of Suillus luteus from mineral-rich soils showed greater tolerance to zinc and cadmium, but not to copper or nickel (Colpaert et al. 2000). C. geophilum isolates from serpentine and nonserpentine soils differed in restriction and amplified fragment length polymorphism patterns (Panaccione et al. 2001). Cenococcum from other sites also harbors significant phylogenetic divergence, unexpected in an organism not known to have sexual reproduction (Douhan and Rizzo 2005). This study was designed to distinguish species, but not ecotypes.
Although some fungal species were found only on serpentine soils, the heterogeneity of soils and the patchiness of fungal dispersion, as evidence by the high coefficients of dispersion, prevented recognition of serpentine-specific species. The common mycorrhizal species are widespread and tolerant of serpentine conditions, thus they do not create distinct soil-specific groups. This study showed that the most frequent ectomycorrhizal species associated with $Q$. garryana were not excluded by serpentinite or peridotite parent materials and that no new species with frequent occurrences appeared solely on serpentine soils. The implication of this finding is that new root tips of either seedlings or established plants may obtain mycorrhizal inoculum from fungi on adjacent non-serpentine sites. Ectomycorrhizal plants on serpentine soils are not restricted by dispersal of spores among serpentine sites.

Acknowledgements This research was supported by National Science Foundation Grant DEB-0516229 to D. Southworth through Research at Undergraduate Institutions.

Open Access This article is distributed under the terms of the Creative Commons Attribution Noncommercial License which permits any noncommercial use, distribution, and reproduction in any medium, provided the original author(s) and source are credited.

\section{References}

Agerer R (1991) Characterization of ectomycorrhizas. Methods Microbiol 23:25-73 doi:10.1016/S0580-9517(08)70172-7

Alexander EB, Coleman RG, Keeler-Wolf T, Harrison S (2007) Serpentine geoecology of Western North America. Oxford University Press, New York, p 512

Alexander EB (1988) Morphology, fertility, and classification of productive soils on serpentinized peridotite, California. Geoderma 41:337-351 doi:10.1016/0016-7061(88)90069-9

Altschul SF, Gish W, Miller W, Myers EW, Lipman DJ (1990) Basic local alignment search tool. J Mol Biol 215:403-410

Avis PG, McLaughlin DJ, Dentinger BC, Reich PB (2003) Longterm increase in nitrogen supply alters above- and belowground ectomycorrhizal communities and increases the dominance of Russula spp. in a temperate oak savanna. New Phytol 160:239-253 doi:10.1046/j.1469-8137. 2003.00865.x

Brady KU, Kruckeberg AR, Bradshaw HD (2005) Evolutionary ecology of plant adaptation to serpentine soils. Annu Rev Ecol Evol Syst 36:243-266 doi:10.1146/annurev. ecolsys.35.021103.105730

Brooks RR (1987) Serpentine and its vegetation. Dioscorides, Portland, p 454

Bruns TD, Szaro TM, Gardes M, Cullings KW, Pan JJ, Taylor DL et al (1998) A sequence database for the identification of ectomycorrhizal basidiomycetes by phylogenetic analysis. Mol Ecol 7:257-272 doi:10.1046/j.1365-294X.1998.00337.x 
Cairney JWG, Chambers SM (1999) Ectomycorrhizal fungi: key general in profile. Springer, New York

Colpaert JV, Vandenkoornhuyse P, Adriaensen K, Vangronsveld J (2000) Genetic variation and heavy metal tolerance in the ectomycorrhizal basidiomycete Suillus luteus. New Phytol 147:367-379 doi:10.1046/j.1469-8137.2000.00694.x

Douhan GW, Rizzo DM (2005) Phylogenetic divergence in a local population of the ectomycorrhizal fungus Cenococcum geophilum. New Phytol 166:263-271 doi:10.1111/j.14698137.2004.01305.x

Frank JL, Southworth D, Trappe JM (2006a) NATS truffle and truffle-like fungi 13: Tuber quercicola and Tuber whetstonense, new species from Oregon, and Tuber candidum redescribed. Mycotaxon 95:229-240

Frank JL, Barry S, Southworth D (2006b) Mammal mycophagy and dispersal of mycorrhizal inoculum in Oregon white oak woodlands. Northwest Sci 80:264-273

Gadd GM (1993) Interactions of fungi with toxic metals. New Phytol 124:25-60 doi:10.1111/j.1469-8137.1993.tb03796.x

Gadd GM, de Rome L (1988) Biosorption of copper by fungal melanin. Appl Microbiol Biotechnol 29:610-617 doi:10.1007/BF00260993

Galli U, Schüepp H, Brunold C (1994) Heavy metal binding by mycorrhizal fungi. Physiol Plant 92:364-368 doi:10.1111/ j.1399-3054.1994.tb05349.x

Garcia M (1979) Petrology of the Rogue and Galice Formations, Klamath Mountains, Oregon: identification of a Jurassic Island arc sequence. J Geol 86:29-41

Gardes M, Bruns TD (1993) ITS primers with enhanced specificity for basidiomycetes - application to the identification of mycorrhizas and rusts. Mol Ecol 2:113-118 doi:10.1111/j.1365-294X.1993.tb00005.x

Grace JB, Safford HD, Harrison S (2007) Large-scale causes of variation in the serpentine vegetation of California. Plant Soil 293:121-132 doi:10.1007/s11104-007-9196-6

Harper G (2003) Fe-Ti basalts and propagating-rift tectonics in the Josephine Ophiolite. Geol Soc Am Bull 115:771-789 doi:10.1130/0016-7606(2003)115<0771:FBAPTI >2.0.CO;2

Horton TR, Bruns TD (2001) The molecular revolution in ectomycorrhizal ecology: peeking into the black-box. Mol Ecol 10:1855-1871 doi:10.1046/j.0962-1083.2001.01333.x

Jentschke G, Godbold DL (2000) Metal toxicity and ectomycorrhizas. Physiol Plant 109:107-116 doi:10.1034/j.13993054.2000.100201.x

Kruckeberg AR (1984) California serpentines: flora, vegetation, geology, soils, and management problems. University of California Press, Berkeley

Kruckeberg AR (1986) An essay: the stimulus of unusual geologies for plant speciation. Syst Bot 11:455-463 doi:10.2307/2419082

Kruckeberg AR (1992) Plant life of western North American ultramafics. In: Roberts BA, Proctor J (eds) The ecology of areas with serpentinized rocks: a world view. Kluwer, Dordrecht, pp 31-73

Kruckeberg AR (2006) Introduction to California soils and plants. University of California Press, Berkeley, p 286

Lee BD, Graham RC, Laurent TE, Amrhein C, Creasy RM (2001) Spatial distributions of soil chemical conditions in a serpentinitic wetland and surrounding landscape. Soil Sci Soc Am J 65:1183-1196

Maas JL, Stuntz DE (1969) Mycoecology on serpentine soil. Mycologia 61:1106-1116 doi:10.2307/3757496
McCarthy C (1998) Chromas 1.45. School of Health Science, Griffith University, Southport

McCune B, Grace JB (2002) Analysis of ecological communities. MjM Software Design, Gleneden Beach

McCune B, Mefford MJ (1999) PC-ORD, Multivariate analysis of ecological data, version 4. MjM Software Design, Gleneden Beach

Meharg AA, Cairney JWG (2000) Co-evolution of mycorrhizal symbionts and their hosts to metal-contaminated environments. Adv Ecol Res 30:69-112 doi:10.1016/S0065-2504 (08)60017-3

Moser AM, Petersen CA, D'Allura JA, Southworth D (2005) Comparison of ectomycorrhizas of Quercus garryana (Fagaceae) on serpentine and nonserpentine soils in southwestern Oregon. Am J Bot 92:224-230 doi:10.3732/ajb.92.2.224

O'Hanley DS (1996) Serpentinites: records of tectonic and petrologic history. Oxford University Press, London

Oze C, Fendorf S, Bird DK, Coleman RG (2004) Chromium geochemistry in serpentinized ultramafic rocks and serpentine soils from the Franciscan complex of California. Am J Sci 304:67-101 doi:10.2475/ajs.304.1.67

Panaccione DG, Sheets NL, Miller SP, Cumming JR (2001) Diversity of Cenococcum geophilum isolates from serpentine and non-serpentine soils. Mycologia 93:645-652 doi: $10.2307 / 3761819$

Ramp L, Peterson NV (1979) Geologic map of Josephine County, Oregon. Bulletin 100, Geology and mineral resources of Josephine County, Oregon. Department of Geology and Mineral Industries, Salem

Richard F, Millot S, Gardes M, Selosse MA (2005) Diversity and specificity of ectomycorrhizal fungi retrieved from an old-growth Mediterranean forest dominated by Quercus ilex L. New Phytol 166:1011-1023 doi:10.1111/j.14698137.2005.01382.x

Sokal RR, Rohlf FJ (1996) Biometry. The principles and practice of statistics in biological research. Freeman, New York, p 87

Taylor AFS (2002) Fungal diversity in ectomycorrhizal communities: sampling effort and species detection. Plant Soil 244:19-28 doi:10.1023/A:1020279815472

Thompson JD, Gibson TJ, Plewniak F, Jeanmougin F, Higgins DG (1997) The Clustal X windows interface: flexible strategies for multiple sequence alignment aided by quality analysis tools. Nucleic Acids Res 24:4876-4882 doi:10.1093/nar/25.24.4876

Valentine LL, Fiedler TL, Hart AN, Petersen CA, Berninghausen HK, Southworth D (2004) Biodiversity of ectomycorrhizal fungi associated with Quercus garryana. Can J Bot 82:123-135 doi:10.1139/b03-117

Walker JF, Miller OK, Horton JL (2005) Hyperdiversity of ectomycorrhizal fungus assemblages on oak seedlings in mixed forests in the southern Appalachian Mountains. Mol Ecol 14:829-838 doi:10.1111/j.1365-294X.2005.02455.x

White TJ, Bruns T, Lee S, Taylor J (1990) Amplification and direct sequencing of fungal ribosomal RNA genes for phylogenetics. In: Innis MA, Gelfand DH, Sninsky JJ, White TJ (eds) PCR Protocols: a guide to methods and applications. Academic, New York, pp 315-322

Wright JW (2007) Local adaptation to serpentine soils in Pinus ponderosa. Plant Soil 293:209-217 doi:10.1007/s11104006-9181-5 